\title{
A case study on the downfall of kingfisher airlines
}

\author{
Ashok Panigrahi ${ }^{1 *}$, Antra Sinha ${ }^{2}$, Anshul Garg ${ }^{3}$, Astha Mehta ${ }^{4}$ \\ ${ }^{\mathbf{1}}$ Associate Professor, ${ }^{2-4}$ Student, Dept. of Management, MBA Tech Students, SVKM'S NMIMS, Maharashtra, India
}

*Corresponding Author: Ashok Panigrahi

Email: panigrahi.ak@gmail.com

\begin{abstract}
Kingfisher Airlines Ltd. was owned by biggest liquor tycoon of India with an ambition to become an industry leader. Growing share in aviation market, wide number of destinations and numerous awards, depicted a very attractive and innovative picture for the company. Kingfisher airlines achieved success in gaining customer satisfaction by offering great and comfortable flying experience to its passengers. However, in the Indian aviation sector, Kingfisher Airlines had a short but lasting impression.

By the end of 2011, Kingfisher Airlines suffered a huge financial crisis. Kingfisher Airlines, UB Holdings Ltd. was provided loan by many private and public sector banks in India, considering the reputation of its CMD. He was unable to repay loans to many public sector banks, however private banks recovered all loans.

This paper describes the downfall of Kingfisher Airlines and the study of financial condition of United Breweries Holdings. Here, we have tried to understand the business of Kingfisher Airlines and studied the role of banks in extending loans and recovery attempts. Moreover, we have attempted to emphasize the reasons behind the financial failure of the company from the point of view of mistakes in strategic decision making.
\end{abstract}

Keywords: Kingfisher airlines, Vijay Mallya, Aviation industry, Bankrupt.

\section{Introduction}

India's one of the most highly profiled airlines- Kingfisher, has turned into shambles whereas in the market scenario, other competitors of the Kingfisher are flying high.

During the year 2012, Global aviation industry was going through a challenging phase due to ground breaking fuel price hike for the last 4 years, tumultuous financial markets and economic slowdown. Vijay Mallya's dream venture, Kingfisher Airlines -widely known as The King of Good Times - witnessed its worst phase.

Kingfisher initially launched as the all-economy, with single-class layout aircraft with high quality eatables and entertainment systems. Vijay Mallya's jovial nature, knew well enough how to live the life of a king, and focused only on this thought that each air traveler would expect their travel similar to a king's journey in the Kingfisher Airlines. A year later after the airline was set up, the focus shifted to the high luxury class. The airline could not hold stability with changing time and ideas of its models and expecting random expansion.

The misguided government policies made entire Indian domestic aviation suffer from a serious market failure, and thus the ministers were needed to step in quickly to fix it. Kingfisher, the debilitated airline asked for life support from the government and banking sector and focused to manage much of the business funds with outside money.

Since 2005, as the airline initiated operations, the business is proclaiming the losses. In India, a large number of aircrafts were added by most of the upcoming airlines since 2006 and they deployed them mostly on metro sectors which resulted into baneful price war among all the airlines. Even today, almost every airline in India is suffering operating losses.

But after the company acquired Air Deccan in the year 2007, the situation became even more dreadful and this made the airline face financial issues for long. Kingfisher Airlines holding second largest share in India's domestic air travel market till December 2011, faced extreme financial crisis.

\section{Background of the Company}

Kingfisher Airlines was established in the year 2003 and owned by the United Breweries Group which is based in Bengaluru. It came into the aviation market at a time when the low cost airlines had galvanized the market and made air-travel available to every Indian.

The promoter of the airline, India's biggest liquor tycoon Mr. Vijay Mallya was well known for his vibrancy, quality and style. He upholds the legacy of his family business at the age of 28 and his luxurious lifestyle gave him the corporate fame at quite an early age. He used his popularity to uplift United Breweries Groups brand and invented "King of all times" slogan for the beer. Starting off as the Chairman of UB Group, his international blitz of buying and selling Berger Paints U.K. and spending money on fast cars, yachts and many international homes remodeled him to its brand icon.

"My own lifestyle got intertwined with brand personality and so without really planning it that way I became almost my brand ambassador of and that's just the way it's kept on developing" he once said. This slogan led to the creation of a brand image of Kingfisher airlines. The company possessed two subsidiaries Vitae India Spirits and, Northway Aviation. The Aircraft acquisition and financing pre-delivery payments was taken care by Northway Aviation.

On $9^{\text {th }}$ May 2005 Kingfisher airlines started commercial operations with four brand new Airbus A320 - 200s, which operated between Delhi and Mumbai on a daily basis. The company aimed to provide world class facilities and lead the 
competition in products well as service offerings, with brand new planes and excellent facilities like: hot meals, comfortable seats, personalized entertainment and treating passengers as "guests". With this kind of an approach, the company started with 4 flights in a day between Delhi and Bangalore, and further increased it to 104 flights per day by introducing 17 aircrafts and connecting 16 cities in one year and setting record in 2005-2007, of fastest airplane induction.

By the year 2006, the Airlines achieved a five-star status and were popular among the business class travelers. It also offered personalized live in-flight entertainment by collaborating with Dish TV India Limited.

By connecting Bengaluru with London, the airline commenced its international operations on $3^{\text {rd }}$ September 2008. During the year 2008, the company attained the reputation for being the only five star air travels in India and came to be known for rendering excellent flight services to its travelers and maintained its position for the next three years.

In 2009, Kingfisher won numerous accolades across the globe and it was one of the only seven airlines which got 5star rating by Skytrax. Eventually it became the largest airline of the second most populated country in the world with $26.7 \%$ share in aviation market. Kingfisher Airlines operated around 250 daily flights. In May 2009, Kingfisher Airlines got the highest share in aviation market among all the airlines in India by carrying more than 1 million passengers.

At that time three classes of travel were offered by Kingfisher airlines to its travelers: Kingfisher First: which was the business class service mainly focused on people who can afford premium services, Kingfisher Class: the Premium Economy service for the middle-class people who were trendy and upwardly mobile and Kingfisher Red: Low fare basic class which was another name for Air Deccan and focused on the middle class people who were price conscious. In the year 2011, it was once again awarded the best Indian airline of the year. However, it reported a loss of Rs.1,000 crore for three consecutive years.

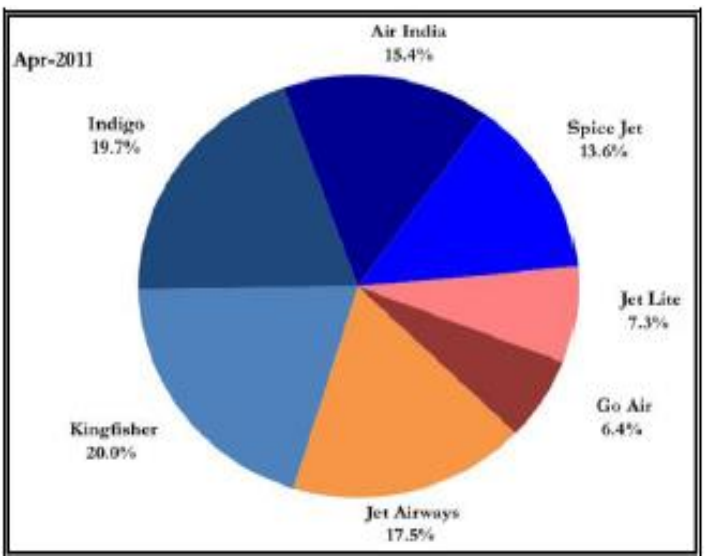

Fig. 1: Market share of aviation sector as on April 2011

\section{Vision of Kingfisher}

"The Kingfisher Airlines family will consistently deliver a safe, value-based and enjoyable travel experience to all our guests."

\section{Start of the Bad Time}

There was a time when Kingfisher airlines was one of the best rated airline in India and got success in gaining customer satisfaction, but it failed to sustain that for a long time.

With the economic slowdown in 2008 and the increasing fuel prices as well as the KFA's mandatory requirement to provide services on non-profitable routes, the path ahead was full of difficulties. The cash strapped Kingfisher airlines was caught in a precarious web and burdened under huge debt, which it owed for airport fees, fuel, and salaries to employees, repayment of loans to different banks and service tax.

In Sept 2010, ex-CEO of SpiceJet, Sanjay Agarwal, joined Kingfisher Airlines and Vijay Mallya assumed the role of MD and Chairman of Kingfisher Airlines. In September 2011, in order to get along with the cash crunch, kingfisher airlines decided to exit Kingfisher Red, which was its low cost segment, but the survival mantra was very late for the ailing airlines.

According to the Kingfisher Airline's annual report for the year 2011, reasonable doubts over the company's existence were raised and it was pointed out that the government money had not been deposited by the airlines, which it deducted as TDS and provident fund contribution, highlighting scruffy financial sustenance of the company. With the passage of time the situation of the company got worse, leading to termination of international flights and cancellation of domestic flights, which is still continuing unabated. On $25^{\text {th }}$ April, 2012 its languishing shares hit an all-time low of 13 .

During the year 2012, losses of over Rs. 7,000 crores were accumulated by the company, with about half of its aircrafts grounded and many members of its staff going on strike. As all its operation suspended, the airline came to a halt.

In view of these predicaments, Vijay Mallya appealed the government for a bailout, but was refused the same. DGCA suspended its flying license on $20^{\text {th }}$ December 2012, and the airline had to shut down its operations.

\section{Rule}

The ministry set Directorate General of Civil Aviation (DSCA) rule drafted in July 2010, as bases for the argument that allowed the airline to function if it would possess five aircrafts and had a capital paid-up for no less than Rs 50 crore. Kingfisher airlines for over a year kept on cancelling the scores for flights under a debt, of more than Rs 7,000 crore and liabilities over Rs 4,000 crore.

Lessor have confiscated its aircraft, which significantly reduced its fleet. The ministry was proved unsuccessful to mention the rule which states that an airline's license is a subject to "mitigation of potential risk factors" discovered 
during a financial surveillance, ensuring safety was not accommodated due to the airline's financial pressure.

\section{Causes}

There was the severe need to identify airline cause for distress considering financial and operational issues to ensure safety functions don't get affected. The possible unfavorable trends in the operator's financial state could include:

1. Decrease in safe operating standards or evidence of cutting corners.

2. Fall in training standards.

3. Significant turnover of personnel.

4. Delayed meeting payroll.

5. Insufficient aircraft maintenance.

6. Storage for supplies and spare parts.

7. Decrease in frequency of flights.

8. Sales or repossession of aircraft and other major equipment items.

\section{Reasons behind the Downfall}

Till December 2011, KFA was considered among top 5 passenger airlines in India but after that it suffered high losses, heavy debts and finally shutdown in 2012. From the data collected, it depicts that there are more business reasons as compared to marketing reasons behind the failure of KFA.

The main marketing reason responsible for the decline was the merging of KFA with Air Deccan and starting of Kingfisher Red.

\section{Operational Reasons}

1. The maintenance, navigation, landing cost of KFA in 2012 was about $10.86 \%$ of the total revenue generated and 3\% more than that of Jet Airways.

2. The employee cost of KFA was also higher than any other airlines.

3. The cost of Value added Services (VAS) by KFA was also very high and also they paid less attention on cleanliness, connectivity, scheduling and low prices that were the basic requirements of Indian customers.

From the reports generated and studies conducted it shows that the condition of Aviation Industry in India was in so much pain that it adversely affected the KFA. There were 4 factors responsible for bad condition of Aviation Industry in India.

\section{Rise in Fuel Prices}

Due to rising demand for fuel and competition among various airlines there was continuous increase in the price of jet fuel and KFA was not able to pay the bills of fuel consumed.

\begin{tabular}{|l|l|l|}
\hline $\begin{array}{l}\text { FUEL } \\
\text { EXPENSES }\end{array}$ & \multicolumn{2}{|l|}{ KINGFISHER } \\
\hline YEAR & 2012 & 2011 \\
\hline REVENUE & $582,400.00$ & $649,560.00$ \\
\hline $\begin{array}{l}\text { FUEL } \\
\text { EXPENSES }\end{array}$ & $294,590.00$ & $227,400.00$ \\
\hline$\%$ & $50.58 \%$ & $35.01 \%$ \\
\hline
\end{tabular}

Fig. 2

From the above table it is clear that in $201250.58 \%$ of their revenue is fuel expenses and out of which their fuel payment was $31.78 \%$ of their revenue. Their fuel expenses were increased by nearly $70 \%$ and because of their nonpayment of fuel expenses many vendors' filed a petition with Bangalore High Court against KFA including BPC (Bharat Petroleum Corporation).

Also the Aviation Turbine Fuel is heavily imposed by Government of India. In India ATF is approx. 51\% higher than the international standard.

1. Fall in Rupee

2. High cost of landing fee and airline taxes

3. Price cutting by AIR INDIA

\section{Worst Decision Made}

In 2007, KFA merged with Air Deccan that was a low-costcarrier that charges low fares while kingfisher was a high cost carrier that was known for its luxury. Kingfisher thought that Air Deccan was in market before it so it would uplift the financial position of the company and another reason was that Kingfisher didn't have 5 years of domestic experience but Air Deccan had and to get international license in aircraft it must have 5 years of domestic experience that is why it acquired Air Deccan.

After merging with Air Deccan there was introduction of Kingfisher Red in 2008. But this business strategy caused confusion in consumer's mind because the KFA passengers were used to the luxury provided like cuisine and lounge access etc. The merging degraded the brand status of KFA and the company lost its premium value.

The company incurred a loss of more than 10 billion for 3 years after merging with Air Deccan. When Kingfisher gets to know that they did a big mistake by acquiring Air Deccan, it increased the prices of Kingfisher Red. But Kingfisher Red was also not a good option at that time because it was under loss and this created confusion among the management to call it a low cost or normal carrier. In December 2011, Income Tax Department of Mumbai freeze the bank accounts of KFA because of due of Rs 70 crores. To pay the debt the company took more loans. For debt reconstruction the lenders who lend loan cut the interest rates and converted the loan to equity. But this was also not helpful to the company as liquidity problem was faced by the company after that. Kingfisher Red was finally shutdown in February 2012. Now KFA is under a total debt 
of Rs 7057.08 crores (USD 1414 million) and total losses of Rs 6000 crores (USD 1202 million.

\section{Strategic Issues}

1. The major mistake committed by Mr. Mallya is that he failed to make proper decisions. He failed to understand the requirement of consumers and made all decisions on the basis of luxury sells. For him airlines were considered to be a luxury travels but in India only selected classes were ready to pay extra for luxury.

2. Mallya being a liquor tycoon was unable to identify the differences between the two industries. Customer might pay extra for alcohol but not for transport, because transport is type of necessity than luxury.

3. In 2008 Deccan airlines was rebranded as Kingfisher Red by Mr. Mallya. So Kingfisher Airlines operated both business and economy class airlines. This looks perfect but wasn't actually. Mr Mallya was in different businesses at the same time. For his liquor business officials were appointed but for airlines all was going by itself. The business needed the attention of $\mathrm{Mr}$ Mallya.

4. According to reports, 366 domestic flights, 20 international flights were flown by KFA. It also owned 67 aircrafts. This increases aircraft lease rental. In 2011, the lease rental crossed Rs. 984 crores and because of this, 66 aircrafts have been grounded.

5. In 2011 there was a time when Kingfisher was not able to pay the salaries to employees. Salaries were due for 4 to 5 months. After this the employees started refusing to sign the mandatory "Tech Log" which states that aircraft is fit and ready to fly. This was noticed by Directorate General of Civil Aviation (DGCA) and they cancelled the license of KFA.

\section{Economic Slowdown}

Economic slowdown in 2008 is another external factor for downfall of the Kingfisher. In 2008, first international route from Bangalore to London was set up. Because of downturn, fuel prices of airplanes raised landing charges at international airport which highly impacted Kingfisher airlines.

\section{Lack of Proper Management}

The frequent change of CEO for more than once in a year and malfunctioning of top level management, which Mr. Vijay Mallya never took any serious intervention in day-today operations. Later airline was gifted to Siddarth Mallya (son of Vijay Mallya) by his father on birthday. He lacked the maturity to handle such a big airlines business and so, lack of correct proficiency and experience in the airline industry, kingfisher airlines suffered severe downfall due to lack of proper management.

\section{Bank Dues}

According to a report generated by "The Indian Express" in November 2015, Mr. Mallya suffered a total loss of Rs $9,091.40$ crore. He took loan from 17 banks. His highest debt was with State Bank of India of Rs. 1600 crore. From the above data the airline owes Rs 800 crore each to Punjab National Bank and IDBI Bank. It also owes Rs 650 crore to Bank of India, Rs 550 crore to Bank of Baroda, Rs 410 crore to Central Bank, Rs 320 crore to UCO Bank, Rs 310 crore to Corporation Bank and Rs 430 crore to United Bank of India, among others, data showed.

\section{Conclusion}

Indian airline business has seen ideal growth and revolution which will go on in coming years. Many airlines come and go while the others have gained a strong ground in this business. The grand and ambitious Kingfisher Airline's project suffered huge downtime due to improper strategic decisions and mismanagement by the group. Instead of trying to utilize this grand airline project opportunity, Vijay Mallya focused to achieve a glamorous status. The airline became for the luxurious design, food and ambience including big goals for settling in international market but neglected the basic economic class. The strategy practiced by Vijay Mallya could not sustain for long and proved to be a great threat at a large scale to both, sustainability and stabilization of the aviation sector. Mallya is now the only board member left holding on to the brand.

For a business to be successful the main focus should be on creating an efficient work-frame, taking appropriate decisions, establishing healthy competitive environment, improving quality of service and standing in unity to find best solutions to problems.

\section{Conflict of Interest: None.}

\section{References}

1. Air Deccan is now Kingfisher Red - Times of India

2. Strategic Mistakes That Led To The Failure Of Kingfisher Airlines

3. Kingfisher default bill: This is how much defunct airline owes to banks; largest dues to SBI - The Financial Express

4. "Kingfisher Airlines: Too big to fail, too big to save", The Economic Times, 21 November 2011. - Google Search

5. Air Deccan is now Kingfisher Red - Times of India

6. https://economictimes.indiatimes.com

7. https://www.peoplematters.in

8. http://tejas.iimb.ac.in

9. https://www.theijbm.com

10. https://economictimes.indiatimes.com/industry/transportation/a irlines-/-aviation/why-vijay-mallyas-kingfisher-airlines-is-stillnot-grounded/articleshow/15238586.cms?from $=\mathrm{mdr}$

11. https://www.thehindu.com/business/companies/the-rise-andfall-of-a-castle-in-the-air/article2622215.ece.

How to cite this article: Panigrahi A, Sinha A, Garg A, Mehta A. A case study on the downfall of kingfisher airlines. J Manag Res Anal 2019;6(2):81-4. 